\title{
ETRUSCAN MALENA "MIRROR"
}

Etruscan malena "mirror"1 is an adjective in -(e)na derived from *mal"to look, to see" as Slavic *zbrkadlo "mirror" (SCr. zrrcalo, Russ. zérkalo etc.) came from *zbrkati "to look, to see" (Russ. dial. zérkat', compare Osl. zbrèti etc.).

This hypothetic Etruscan *mal- obviously is the reflex of Nostratic root

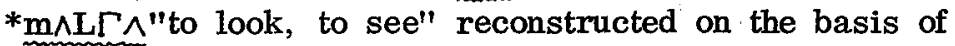

HS *ml in Cush. *mnllic - "to look": Bilin milie j- "to look (about, around)", Kwara mäl- "to look about/around", to observe"; Kimant mēl- "to look"; Somali: mala "thought", I-saq malaj- "to think, to guess"; Oromo mil' u"look", mil'ad-/-t- "to look", mal- "to think, to guess", mala "thought"; Sidamo mal- "to consult, to talk over"; Ometo Wolamo mil- "to believe";

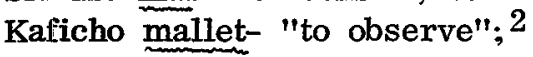

IE *mel- "to show onelesf": OIr. mala f. (gen. malach) "eye-brow", Gaelic mala f. (pl. malaichean) id.; S1. *moliti: Slov. molíti "to stretch out", SCr. izmòliti "to show oneself, to appear, to emerge", Sorb. pomaleć so, Sorb. pomalaś se "to become bare shamelessly, to open", Ukr. *mylaty "to be visible". 3 This root is not connected with *mel- "mountain".

?Alt. *muli "to think": Monghuor mūla- "to think"; 5 Tung. *muli: Evenki muli "thought", muli- "to think", Even múliń- "to think"; 6 . ?Japanese miru "to see, to look"; 7

1 A.J. Pfiffig, Die etruskische Sprache, Graz 1969, p. 294: malena "Spiegel ?", malstria id., mal- "?".

2 A.B. Dolgopol'skij, Sravnitel'no-istoričeskaja fonetika kušitskih jazykov, Moscow 1973, p. 180.

3 L.V. Kurkina, Slavjanskie ètimologii III - "Étimologija 1973", p. 34-8.

4 Pokorny 721-2; V.M. Illič-Svityč, Opyt sravnenija nostratičeskih jazykov II, Moscow 1976, p. 51 - compares IE *mel- "mountain, height" with Drav. *mal- "mountain".

5 B.H. Todaeva, Mongorskij jazyk, Moscow 1973, p. 347.

6 Sravnitel'nyj slovaŕ tunguso-mańčžurskih jazykov I, Leningrad 1975,p.555.

7 C.J. Dunn - S. Yanada, Japanese 12 , London 1976, p. 294. 
Nivkh *mal- "*what is visible, what is near" in malagud" "to bring nearer, to draw near", malajvid" "to approach", malaf "not far away, hereabouts, near by". 8

\section{Sažetak}

\section{ETRURSKI MALENA "ZRCALO"}

Hipotetička etrurska osnova *mal- sadržana u riječi malena "zrcalo" refleks je nostratičke osnove ${ }^{*} \mathrm{~m} \wedge \mathrm{L} \Gamma \wedge$ "gledati, vidjeti" rekonstruirane na osnovi kuš. *m^ll^^- "vidjeti", ie. *mel- "pokazati se", ? alt. *muli "misliti", nivh. *mal- "što se vidi, što je blizu".

8 V.N. Saveleva - Č.M. Taksami, Nivhsko-russkij slovaŕ, Moscow 1970, p. 173 . 